$$
11-12-93
$$

WORKSHOP IN POLITICAL THEORY

AND POLICY ANALY,

513 NORTH PARK

INDIANA LINIVERSITY

BLOOMHAGTON, INDIANA 47458-3186

Reprixt File CPR

\title{
A FOREST BEYOND THE TREES: TREE CUTTING IN RURAL GHANA
}

\author{
George J. S. Dei \\ Department of Sociology and Anthropology \\ and the \\ Institute for international and Developmental Studies \\ University of Windsor
}


ABSTRACT

This paper examines the complexity of human forces involved in the processes of tree cutting in a Ghanaian forest region. It provides evidence to link the indiscriminate tree cutting activities in some local communities to the gradual loss of communal control over land and the replacement of kin group control with state property regimes. The author points to the interrelated factors of the state's promotion of an export-led development strategy and the intensification of agricultural commercialization, as well as household and group differential and unequal access to land as all having a deleterious impact on local traditions of sustainable forestry.

Key words: Sustainable forestry, deforestation, land tenure, rural economy, Ghana, West Africa. 


\section{INTRODUCTION}

Among the major environmental and developmental problems facing humankind today is how to sustain the world's forests by developing structures and patterns best suited to both harvesting and protecting environmental resources. Ecologists have generally highlighted the importance of forest environments in maintaining the stability of the global ecosystem and in preserving biological diversity (Friday and Laskey, 1989; Myers, 1989; Bolin, 1989). The general public is gradually becoming aware of the dangers associated with the so-called greenhouse effect in the debate over, and condemnation of the on-going destruction of the Amazon forest in South America. We are reminded that the Amazon Basin forest in Brazil is home to at least 20 per cent of the earth's birds and over 2,000 species of trees and fishes (May 1989). Yet over 12 per cent of the forest has already been destroyed according to World Bank estimates. Responsibility for the destruction is traced to the slash and burn activities of landless peasants as they clear land for cattle ranching, the operations of paper and pulp mills (particularly that associated with the Jari project), as well as the 420 other timber contracting multinational firms in the region.

It is clear that there are varied objectives involved in trying to maintain the forest at the local, regional, national and international levels. There is a problem of reconciling the usually conflicting and/or competing interests and aspirations of the human agents and forces involved. The situation has in most cases prevented the development of effective management systems and programs to take care of the forests at both local and state levels. For the majority of developing countries, the primary aim of state forestry programs is the long-term sustainability of fibre for exports in order to secure hard currency to pay for national imports. In most cases the focus of forest management has been the production of timber and fibre for industrial usage. To many of these governments and their external accomplices, the 
multinational logging companies operating in their regions, trees whether in a virgin and secondary forests or are human planted are there for harvesting. They find the short-term profit motive and incentive far outweighing any local concerns to preserve the forests. But to many local peoples, the forests are more than mere fibre producers. The forest supports wildlife, holds water and protects local streams and rivulets. It provides valuable plant species for medicinal and other local pharmacological uses. It is the source for local fuel needed for household energy supply (e.g., cooking purposes), and the materials utilized in the provision of other basic household needs (e.g., house construction, household furniture). For indigenous peoples keen on reclaıming their cultural and historical past, the wilderness is also valued for its own sake. It is their home, so to speak, and a place for the conduct of religious rituals. The environmentalism of indigenous peoples is based on an intense recognition of the aesthetic value of nature and its resources.

The continued depletion of the world's forest is a threat to the basic survival of the human species. For parts of sub-saharan Africa, the rainforest constitutes the most important productive resource for people. Contemporary environmental degradation associated with the West African Sahel, where productive agricultural land has been turned into waste land, is attributed to among other things, deforestation, overcultivation and overgrazing. Although it is widely acknowledged that the depletion of the forest and its resources is threatening rural livelihoods, very little attention (if any) has been paid to the nature and processes of deforestation taking place in these communities (Timberlake, 1985; Ellis, 1987). Community-level research on the tree-cutting activities of local populations, the state, and multinational logging companies operating in these regions has been lacking. Such research could account for the gradual erosion, among some rural peoples, of the traditional perception that the forest is a priceless heritage for future generations. We could also fully understand the local-level impact of rising human population 
growth rates, the introduction of more unrestrained farming to meet the demands of an "unlimited" market, and the erosion old taboos protecting the forest from gradual decay.

A major theoretical position in trying to understand the problem of deforestation is to relate poverty to environmental degradation (Redclift, 1987). The approach unduly blames the poor for the problem as if poverty is an independent variable. It does not take into account the fact that for long, rural peoples have been capitalizing on their traditions of sustainable forestry (see Richards, 1983, 1985; Watts, 1984). Poverty and resource abuse, it can be argued, are caused largely by policies and actions of the state and its 'external' accomplices. There are interrelated socioeconomic, ecological, political, and historical factors with both internal and external dimensions that account for the environmental degradation in most communities today. Environmental degradation and human poverty have resulted not only from distributive and exploitive mechanisms, but perhaps more importantly from structural processes. Many rural communities have been drastically transformed as a result of the expansion and contraction of the world economic system. It should also be noted that many rural peoples today cannot change the way they utilize natural resources without a fundamental restructuring of rural production relations. It is important then that this relationship between ecological-economic factors and social structures be understood. We need to study those institutions and practices representing maximum concentrations of power in these societies. Although human poverty has serious implications for environmental degradation, the specificity of the relationship between structural factors and those of the natural environment has not been fully comprehended.

To the extent that many traditional communities in the developing world managed their forests well before the advent of colonialists and the development of cash crop export economies, one can safely argue that the wanton destruction of the 
forest is a relatively modern phenomenon (Brokensha, Riley, and Castro, 1983; Maguire and Brown, 1986; Sinclair, 1986; Ki-Zerbo, 1981). Many rural peoples have traditionally been well-accustomed to shaping and re-shaping their environments to suit their own needs (Richards, 1985; Brokensha, Warren and Werner, 1980). With time they evolved techniques that allowed them to live in a sustainable fashion in their environments. Sustainability, as practiced then, was treating natural resources in a way that did not preclude similar uses in the future. There is little evidence to indicate any indiscriminate felling of trees over and above the immediate needs and requirements of society, to the extent that the forest's ability to sustain itself was jeopardized.

In understanding the problem of tree cutting one has to examine such factors as the changes in land tenure and land use rights that have been associated with the market economy and the export-led development strategies currently been pursued by African national governments. The on-going deforestation must be related to the differential control and access to natural and other land resources that individuals or groups have in society (Fortman and Bruce, 1988). The problem has been exacerbated by the failure of the state to have an effective development strategy for tropical forests, and the unabated pursuit of an export-led development framework. This strategy gives priority to the satisfaction of external needs and interests at the expense of local food self-sufficiency (Rudel, 1989).

The study of local processes of tree cutting links agrarian sociology with agrarian ecology, specifically, in the examination of changes in agricultural practices and their explanation in terms of social processes (e.g., the mechanisms which distribute access to resources among a given population) (see Blaikie 1989:25; Blaikie and Brookfield, 1987]. Compared to food farming, cash (tree) cropping tends to have much more long-term deleterious environmental consequences in terms of the exploitation and use of available land resources (Dei, 1990a). An export-led 
development approach, given world trade patterns, extract huge environmental and social costs. This development approach as is being currently promoted in some countries through the structural adjustment programs of the World Bank and the IMF is incompatıble with sustainable forestry. Besides, the massive foreign debts of these countries is literally forcing them to commit ecocide as they mortgage their environments to finance the interests on such loans.

The examination of how the peoples of one Ghanaian region are deriving their livelihoods reveals the competing roles and interests among local and external forces with regard to the procurement and use of forest resources. At one level among competing interests is local peoples who have their own ideas on how their land should be used. At a second level is the state with its set of development goals and/or agenda influenced to varying degrees by local conditions, by its own members (elite) and by foreign interests. At the third and final level is foreign interests which include those who clear forest vegetation for their own profit (e.g., logging companies) and those who degrade the environment in the name of 'progress' or a higher good (see Adams and Solomon, 1985; Cartwright, 1990). In some Ghanaian communities there is evidence linking indiscriminate tree cutting to the loss of communal control over land the and replacement of kin-group control with state property regimes.

\section{THE RESEARCH REGION}

This case study was conducted in the Ayirebi community, near Akyem Oda in Southeastern Ghana and the surrounding villages and towns of Adubeasi, Odumase, Kofi Nimo, Abenase, and Ofoase (See Figure 1). The town of Ayirebi has been the focus of a longitudinal study that began in the early part of the 1980s. In 1982-83, I studied the adaptive responses of the local peasant farmers to seasonal food supply cycles as well as to the national economic crisis of the early 1980s. The crisis had been 
triggered by the world recession and aggravated by the socioenvironmental stresses of drought, bush fires that destroyed both food and cash crop farms, and the return of over a million Ghanaian nationals deported from Nigeria. In follow-up and comparative studies of the town and other Ghanaian villages in 1989 and 1990, 1 addressed local strategies of rural economic renewal. I focused on the issues of continuities and changes in the contemporary adaptation of the local peoples, specifically the degree and extent to which coping strategies had been continued long after the 1982-83 drought. Gender and household socioeconomic differentiation in local coping strategies were also explored (Dei, 1990a, 1991). A particular research interest of the late 1980s and in 1990 was the examination of the human forces involved in local deforestation processes. To understand the interplay of national, regional and local forces, I collected data on local processes of forest resource exploitation and utilization for the Ayirebi town and the surrounding villages. Through the traditional anthropological methods of participant and nonparticipant observations of household activities, key informant interviewing and collection of individual life histories, I secured information on community myths and taboos protecting the forest from decay, and the local reasons for tree cutting by individuals, household and community groups. Land use and allocation rights and the impact of contemporary agricultural changes (e.g., new cropping systems on forest lands) also studied, as well as the extent and impact of the international trade in timber and/or the exploitation of forest trees by commercial loggers to meet external demands for tropical woods. I received research assistance from a student of the University of Ghana and another student of the University of Windsor during various phases of my fieldwork. 


\section{Rural Ecology and Economic Production}

The study region is predominantly inhabited by Twi speaking peoples belonging to the matrilineal Akan subgroup, Akyem. The Ayirebi town specifically has a population of 5,8051 primarily consisting of peasant farmers. Each of the surrounding villages has less than 4,000 people. The local farmers cultivate such food crops as plantain, cocoyam, cassava, yam, rice and green leafy vegetables. Cash (tree) cropping involving cocoa, oil palm, and citrus fruits is a relatively recent activity in the region. Local articulation with the market and/or wage economy involves the sale of foodstuffs, traditional arts and crafts, and wage labour in major Ghanaian cities and urban centres. The region experiences a main dry season between January and March when the farming season begins with preparation of the farm fields (i.e., cutting, burning, and tilling of farm land). The mean monthly rainfall during this time is less than $100 \mathrm{~mm}$. It is followed by the main rainy season from April to June when farming activities continue with the sowing of seeds and crop planting. The heaviest rains fall in June. The period between July and September marks the pre-harvest, lean season devoted to weeding of farm fields and attending to crops. There are two brief intermediate climatic seasons during this period. Low rainfall and moderate dry conditions are experienced in July and August while September and October mark the beginning of the second rains. The main harvest season, October to December, marks the beginning of the dry conditions that continue and intensify through March. The intense dry period is locally referred to as the harmattan 2 period. Until the late 1970 s annual rainfall in this region averaged over $1,650 \mathrm{~mm} .3$ In the $1980 \mathrm{~s}$, and since the beginning of the $1990 \mathrm{~s}$, there has been a reduction in rainfall, averaging $1300 \mathrm{~m}$. Particularly during the drought period of 1982-83 annual rainfall in the region fell to $933 \mathrm{~m}$ (Dei, 1988). The most characteristic feature about the climate of this region (as in Ghana generally is humidity. The average relative humidity is between $85-90$ per cent 
which dropped to 66 per cent in the 1980 s. Temperature variation is slight. The mean monthly maximum temperature in the hottest months (February-March) is $31^{\circ}$ $33^{\circ} \mathrm{C}$, while the mean monthly minimum in the coldest months (December-January and August) is between $19^{\circ}-22^{\circ} \mathrm{C}$ (Hall and Swaine, 1981). The changes in climatic conditions are part of the long-term consequences of the on-going deforestation in the whole region.

Table 1 shows the distribution of vegetation cover in Ghana. Table 2 is the periodic mean rate of loss of vegetation cover to agricultural activities. The largest portion (at least 65 per cent) of the forest is secondary vegetation with the forest reserves comprising not more than 25 per cent of pristine environment. 4 Much of the pristine forest land is under state control (i.e., state property regimes). The study region is a moist semi-deciduous forest zone consisting of moderately grouped lofty trees (about $60 \mathrm{~m}$ in average height) with a matted undergrowth (Manoukian, 1964). The forest trees can be classifed into lower and upper storeys. Those in the lower are usually evergreen, while the taller members of the same species exhibit deciduous characteristics during the harmattan season. There are two major soll types, forest ochrosols and oxysols (Ahn, 1970). Forest ochrosols are predominant and have developed from highly weathered parent materials under reduced amounts of rainfall. Unlike the forest oxysols which are highly leached, yellowish, very acidic, and nutrient poor, the forest ochrosols are less leached, reddish, slightly acid to neutral, and better suppled with nutrients (Hall and Swaine, 1981).

Generally, these local soils are light and sandy, and thus easily cultivated. However, they are poor and rapidly lose their rich organic matter (leaves, animal matter) and are liable to damage by rains unless they are efficiently manured, cultivated, drained, and mulched.

With regard to local structures of local agricultural production, ideally the individual household made up of a man, his wife, and children constitutes the basic 
production unit. This group could either be the sole production unit occupying a house or compound, or it could form part of a larger group occupying a house or compound. In this latter instance, the compound would be sub-divided into a number of separate (and independent) production units. It is also possible for a large group organised around a segment of the matrilineage (an elder woman and her sister or her daughters; or a man and his sister or his sister's children) to be the sole production unit within the compound or dwelling house (Dei, 1986; Hill, 1975). Members of a household share farming activities, working together on land acquired either through the matrilineage or the custodian of the stool (that is, village chief or sub-chief) or through the individual's personal effort (outright purchase). The household head holds the land from which the group obtains its sustenance. Nearly 70 per cent of the land under cultivation in Ayirebi is held by males who also constitute the majority of household heads. In the total research sample of 450 households in 1989 and 1990, 348 (77 per cent) were males and 102 (23 per cent) females. The household head organizes the exploitation of this land and makes most of the production decisions in consultation with other household members. During periods of major economic activity (such as preparation of the land for farming or harvesting of produce when agricultural work intensifies), households may request farm assistance from available extended family labour (Dei, 1988). There are other important "external" sources of labour supply available to household production units such as the use and dependence on seasonal or casual wage labour; and commercial labour, as in the formation of partnerships such as nnoboa, collective self-help groups of age mates helping each other in farming activities (Arhin, 1983).

The adult males perform the task of clearing the forest and preparing the land for farming. Women, the young and the elderly do the planting, attending to the farms and harvesting of the crops. They occasionally receive some assistance from 
the men, particularly when both sexes make joint efforts to keep weeks out of the farm plots. Dei (1990b) has discussed in detail the farming process and the ethnoecological knowledge of the local peoples. Table 3 provides data for the sample of 450 households studied in 1989 and 1990 for the specifics of local farming systems and processes. The principal methods of farming are shifting cultivation on bush farms and intensive cultivation and/or permanent tileage in the gardens and farm plots closer to the homesteads. The farming process involves partial clearance of natural cover on small to moderate size ( $0.4-1$ hectare) isolated farm plots. The traditional farming implements include sekan (cutlass or machete), aso (hoe), abonua (steel axe), akuma (pick axe or mattock), soso (digging stick or long blade). In the mid 1980s, chain saws obtained by local migrants from Nigeria played a significant part in facilitating land clearance for agricultural purposes. Mixed and sequential cropping as practised by local farmers involve planting different crops at different times of the year on the same farm plots. There is usually a fallow period during which the farm plot is cropped for about two years and then allowed to return to bush for a period depending on the amount of farmland available to the farmer. The fallow period allows the bush to produce its own fertiliser in the form of dead leaves, grass, plant roots, branches and other organic material which decompose in and on the soil and improve soil fertility.

The subsistence needs of an increasing population, coupled with the requirements of an external market have led to expansion in the local food economy; When idle land or virgin lands are not being put into cultivation, fallow periods are shortened to about two to three years. As the length of the fallow period becomes insufficient for the forest vegetation to regenerate itself, local farmers have had to rely on constant manuring or intensive cultivation to sustain the fertility of their fields of permanent tillage. The incorporation of crop residues into the soil using manure, fertiliser and compost of animal and occasionally human 
excreta or refuse provides a good source of organic material and plant nutrients to the soil.

An important feature of the farming system, and particularly of bush fallow, is the use of fire for clearing vegetation. After initially clearing the wild vegetation with a cutlass, the farmer will cut lines and smaller trees and bushes into bits and pieces, then pile them up into heaps and allow to dry for at least one week before burning. It usually takes a full day to burn the average size farm thoroughly.

Burning takes place before the rainy season approaches. By gathering the trees and bushes into heaps before burning, it is easier for the farmer to control the fire and to stop it from spreading to the farms of neighbours. Some local farmers clear tracts along their farmland before burnıng as a measure to control the spread of fire. After the burning, the farm plot is then liberally manured with wood ash. Bush burning has been criticized on the grounds that the carbon, nitrogen, and sulphur in the fallow and litter are lost in the burning process, and that the practice builds up fire tolerant, low productive species and causes soil erosion. Burning also exposes the soil to the detrimental effects of the sun and torrential rains until the first crop forms an effective protective cover. However, the danger of soil erosion is considerably reduced since the soil structure is not greatly disturbed by either the use of plough or the uprooting of tree stumps. Due to the fact that the cleared plots are usually small and fringed by uncleared vegetation there is little danger of serious sheet erosion (Benneh, 1973). To local farmers, bush burning saves time and labour and has the net effect of adding some quantities of nitrogen to the unfertilized soil, and thereby improving its fertility. It should also be noted that slash and burn agriculture has long been a practise in this region without much forest destruction because of the ethnoecological knowledge of local farmers. After the burning, the farm plot is still uneven with tree stumps, roots, and termite mounds. In tilling the land, the farmers disturb, loosen, and move small amounts of surface soil as part of 
the farming operation before the actual seed planting takes place (Spencer, 1966). The tilling process is done to prepare the plot afresh for the actual planting of crop seeds. It involves a meticulous process during which farmers may clear any unwanted tree stumps or other weeds that may appear to cause unnecessary harm to a germinating food plant. Weeds whose roots interlock underground making an impenetrable mat (and that have been unaffected by the burning) may be uprooted during the process of tilling the land.

\section{TRADITIONAL LAND TENURE AND CHANGES IN LAND USE RIGHTS}

A crucial factor of rural production and economic development is the access to and control over land. It is also an important factor in the cause of environmental degradation and in shaping peoples responses to it (Blaikie, 1989). The rights of access and control over land in the study region have undergone some changes over the years. To understand these changes it is important that the distinction between access and control over land be clearly spelt out (see Berry 1989:1). The traditional access to land provides individuals with a right to use or benefit from a portion of their social group's land (i.e., land belonging to one's abusua, the matrilineage). However, the control over land, i.e., the effective exercise of such rights rests with the abusuapanyin, the family or matrilineage head. While every citizen may have rights of access to communal land, the effective exercise of such rights has created levels of social differentiation among individuals and groups in the research communities (Dei, 1990a). Generally, individuals and groups have multiple and varied land use rights. Theoretically, there are no exclusive forms of individual land control. It cannot also be argued that the trend towards agricultural commercialization and technical change has so far consolidated land rights in the hands of a few at the expense of many (see Okoth-Ogendo 1989:6-11). But it can be 
substantiated that the on-going transformations in land use rights are generally working to the disadvantage of the poor.

The study of the local farm plots owned by the farming households shows the individual household on the average has between 2-3 different farm plots obtained through a variety of channels. The study also reveals household and gender differentiation in the size of farm plots owned (Dei, 1990a:30-5). The minority of wealthy male household heads tend to have large far sizes that are increasingly being devoted to the cultivation of cash crops while female heads with moderate size plots primarily engage in food production. Traditionally, all land was communally owned, with the town chief acting as the principle custodian. With his consent, land was vested in the matrilineages as corporate groups. Every adult member of the lineage had the right to farm freely and to build on family or lineage land. For the effective exercise of this right to land, custom, however, demanded that the individual first secured the permission of the head of his or her segment of the matrilineage, usually, a mother's brother (maternal uncle) before developing a portion of such land. His primary obligation was to guarantee access to all living members of the group and to preserve the land resources for the benefit of future generations.

Ideally and customarily, an individual could claim a landholding for his sustenance and other basic economic needs, and not purposely for self-esteem or aggrandisement. The lineage land was not subject to outright sale or disposal such that the group's members would lose their rights of access and control over the land. The farmer held only the usufruct of the acquired land. The usufruct is lifelong and transfer of rights to the land upon the holder's death follows matrilineal inheritance. The farmer with rights over such piece of land is ideally subject not only to the control of his or her family and lineage elders, but also, to the ancestors by virtue of his or her spiritual trusteeship to the dead (Rattray, 1923:2229). Land use 
rights could be extended to non-kın members, as for example, in the case of the lineage land being cultivated jointly by members of the holder's household (i.e., spouse and children) and even friends. Thus other channels for obtainıng communal land for cultivation included land acquired from a spouse's lineage as a result of the marital bond. In some cases, a husband may be given a piece of land by his wife's family (usually the mother) upon which to farm, build, or settle. Such land grant is usually made to the man and his issue and not to his heirs, and it can be held as long as he is married to the woman. Upon his death, or in event of divorce, the land would be claimed by his wife and children on behalf of the donor lineage. As part of this arrangement in some cases sons and daughters could use portions of a father's land during his lifetime. Such land however returned to the father's lineage estate upon his death. An alternative arrangement known as sasamansie 5 also allowed spouses and children to have complete access and control over a portion of a husband's and father's lineage land as self-acquired property.

Today, access to lineage land is still defined by descent, affinity, patronage and friendship. The aspect of friendship is important as a local resident or even individuals from other surrounding villages can acquire cultivation rights in land belonging to another lineage on the basis of friendship ties with the lineage head or the member who has initial usufruct rights to the land. In such cases the matrilineage consent is necessary. The practice was observed in the 1980 s when old social ties and linkages were rekindled, and new alliances were created during the stresses of drought, bush fires and the severe contraction of the national economy. This strategy is an important means of increasing diversity of microenvironments a household can exploit, as well as helping to protect against total crop loss or failure due to pests, disease or drought. It is also a means of cementing social networks between individual families and groups (Haugerud, 1989:66-7). 
Another channel of acquiring land use rights is through tenancy arrangement where as in one of its varied forms, a farmer can obtain a portion of land from a landlord in return for a fixed annual payment. Such payment can either be rent-inind (in the form of a proportion of the produce derived from the soil), or rent-in-cash (deriving from the sale of the produce on the market), or it can be in the nature of the farmer providing certain services to the landlord, or a combination of these. Local rentees can negotiate on an abusa basis, i.e., one-third of the farm produce or its cash sale price is for the landlord or the farmer, depending on the nature of the sharecropping arrangement as to who pays for the operational costs. A tenant could also operate under an abunu system, where the entire produce or the amount derived from its sale is shared equally between the landlord and the farmer. 6 Wealthy landlords may also lease their lands to another farmer for a fixed period such as one or two years. During this period, the farmer will cultivate the land and the lease cannot be terminated by the landlord until the stipulated period is over. The leasehold gives usufruct rights to tenants, and the rent paid to the landlord may be in kind or in cash. In situations where the land involved is lineage or family property, the landlord can only lease or rent land after receiving the prior consent of his lineage elders, and in the presence of witnesses. Much of the recent land leased to individual farmers is largely for the cultivation of cash crops and these leased lands are usually those self-acquired by wealthy landlords. There is also mortgaging or pledging of family land to another individual in order to obtain a cash credit or loan. Pledging communal land is rare but permissible if the prior consent of the lineage members is sought for the transaction. The creditor obtains only temporary use rights to the land in question. Such rights are relinquished when the debt is settled. In the event of the debtor's death, the creditor may consult the lineage to settle the debt. Failure to comply may result in permanent alienation of the mortgaged land to the creditor. Although such developments are rare, there are 
cases of permanent alienation after the loss of evidence for such land transactions in the past (see also Okere, 1983). Family members generally resist pledging or mortgaging of group land. Individually acquired lands are therefore more likely to be pledged or mortgaged. In the face of current harsh economic realities, such access to land has been maintained. For the poor it may be a temporary relief to pledge or mortgage land in order to secure financial loans from creditors. In the past wealthy landlords utilised the system as another channel to acquire additional rights to land and to improve upon their wealth .

Another form of communal land is stool land. This is land under the immediate and sole political authority of the town chief. It includes land received as gift or in the form of tribute from other communities. The town chief may either loan or give (as a gift) a portion of such land to any individuals or families in the community to help them alleviate temporary economic hardships. If the land is loaned for farming, the farmer is expected by custom to provide part of the farm produce to the royal household. Such land is still community property and the individual has only use rights. When the chief assigns stool land to a local resident or citizen in recognition of the latter's contribution to the wider community, the recipient has to go through the public payment of aseda (i.e., thanks in the form of token cash payment and customary drinks to the chief and his elders (Mikell, 1984:202-3). Such land is generally considered self-acquired property. Part of the local authorities' strategies to combat the effects of the ecological and economic hardships of the early 1980s involved the granting of temporary use rights to stool lands to the poorer segments of the local communities. In other cases, a town chief in search of funds for commercial projects may decide on the outright sale of stool land. In theory the consent of the town's elders and councillors must be secured prior to the land sales. Some town chiefs have been known not to secure the consent of their elders and to face destoolment charges from their people. 
The transformation of the traditional channels of land acquisition and use has its roots in the emergence of a money economy, wage labour and agricultural commercialization. The outright sale and individual or group purchase of land constitute an affront on the idea of collective ownership of land conveyed by the traditional tenure system. Land is seen by most people today as the most secure form of investment. Traditional institutional measures and sanctions to contain individual alienation of community lands are either proving inadequate or are not strictly followed. There exist, although relatively on a much smaller scale in the study communities than elsewhere in the country, disputes between chiefs and their elders and subjects, or between families and lineage heads over misappropriation of communal lands. Land litigations and disputes have mainly resulted from the improper appropriations of monetary compensations on land transactions contracted by traditional elders. The apparent, increasing contemporary intransignece of certain custodians of lineage lands, can be traced to the necessity for individuals to operate successfully in a competitive economy. Land custodians demonstrate their greed by the manner in which they alienate such land and make use of the savings accrued from the land sales.

\section{LOCAL ATTITUDES, MYTHS AND TRADITIONS ABOUT FOREST TREES}

Trees have traditionally been an aspect of great importance in the normal functioning of rural economies. Certain socio-religious rites and ceremonies (e.g., marriage, male circumcision, and female initiation rites) were conducted under big trees such as "onyina" Ceiba pentandra; "odum" Chlorophora excelsa; and the baobab tree. Some trees were considered sacred because of their significance to the community's cultural history. For example, the nim tree (Alstonia gongensis, "nyamedua")is associated with the early history and settlement of the Ayirebi town. Oral traditions indicate that one of the kings of the powerful Asante nation, Osei 
Bonsu, had planted the tree in the early 19th century to commemorate his rest stop at the early Ayirebi settlement site (Taatim) and the ensuing friendship that developed between him and the chief of the village, Kwayirebi. The sacredness of the nim tree resides in the symbolism of that historical ties that followed the warm hospitality accorded the Asante king and his warriors who were returning from the coast after engaging British colonial forces (Dei, 1986:61-2). Oral traditions also attest to the fact that in the past before any big tree was cut libation was poured for the gods to ask for their blessing and guidance so that no bad omen would befall the community over the decision to cut the tree. Similarly, anytime a big tree fell in the forest due to such natural forces as high winds or for some inexplicable reasons, various mystical, magical and supernatural interpretations were offered to explain the incident. The death of a traditional elder or chief was usually communicated to the people in the language that 'a great tree has fallen'. The reference was to such big trees as "odum", Chlorophora excelsa. Many forest trees which provide shade were used as resting places for people as they passed through the forest in the course of their farming, huntıng and trapping activities. Superstitions prevented trees that people had established some form of quasi-human relations with or attributed some human qualities to from being cut or desecrated.

It is in the light of such local attitudes, myths and traditions regarding forest trees that traditional and customary land use rights have to be assessed and understood. Usufructuary rights to communal lands traditionally did not include a right to indiscriminately dispose of trees on the land. Although individual farmers could cut trees from such communal land in the course of normal farming activities, care was exercised so as not to infringe on certain traditions and myths associated with particular forest trees. Generally forest trees and the land on which they stood were considered to be communal and ancestral property and no individual had the moral authority to alienate such group rights. There was thus a de facto link 
between local traditions on forest trees and customary rights of exploitation and useage of communal lands. Such linkage was only disturbed with the move towards some form of land privitization, state encroachment on communal lands, agriculture commercialization and commercial felling and sale of forest trees to tımber contractors and loggers.

\section{THE CURRENT IMPACT OF COMMERCIAL (TREE CROPPING) AGRICULTURE AND RURAL PROLETARIANIZATION}

Commercial agriculture has a long history in Ghana. However, it was not until the 1970 s that concrete attempts were initiated by the state to diversify the local economy. 7 The early years of the decade was marked by the government's attempts to improve commercial agriculture in the countryside within a capitalist development framework. Much of the period was also characterized by individual land acquisitions of particularly the military and political elite for rice and cash (tree) cropping. For a successful commercialization of local agriculture, the state was urged to reform traditional land tenure and regulate land rights. This it was argued would enhance individual accumulation and/or productivity through private land investments (Kludze, 1983). However, much of the national efforts to increase rural agricultural productivity failed due in large part to the internal problems of political instability, corruption and inefficiency in management, as well as from existing unfavourable terms of international trade.

By the start of the 1980s there was an accelerated decline in the nation's exports, domestic production levels and a growing imbalance between state revenues and expenditures (Hutchful, 1989). The situation was further worsened by the socioenvironmental and economic stressors of drought, bush fires, the return of over $1.2 \mathrm{~m}$ Ghanaian nationals illegally residing in Nigeria, and a global economic recession following the huge increases in OPEC oil prices. To reverse the deterioration in the national economy, the ruling Provisional National Defence 
Council (PNDC) government on the recommendation and guidance of the World Bank and IMF has since the mid 1980s pursued an Economic Recovery and a Structural Adjustment Programmes (ER/SAPs). The goal is to promote national economic growth and improve rural economic conditions through an export-led development framework. The state as liberalized foreign and international trade, deregulated prices and investments, undertaken massive devaluations of the local currency and also rationalized state-owned enterprises through divestment and/or improving efficiency (Hooper, 1990). Some general steps have also been taken to restructure rural production and property relations.

Although there is a historical past to cash (tree) cropping in the research communities, 8 such economic activity has always taken a secondary role in the household food economy. The majority of small-scale farmers devote much of their land, labour and capital resources to food production. Even in some cases, particularly in the 1970s and early 1980s, any cash cropping was strictly tree crop (cocoa) production. It was abandoned in large measure with the fall in world prices, destruction of transportation systems, and the difficulty of food acquisition during the period of ecological hardships (e.g., drought). When in the late 1980s and 1990s conditions have been favourable cash cropping has been re-introduced and/or expanded upon. In the current situation, crop diversification among farming households has involved the establishment of tree crop farms (cocoa, oil palm, citrus fruits), as well as the sole cultivation of tomatoes, beans and rice farms on a wider scale for commercial purposes. The majority of these farms have been established since the latter half of the 1980 s. Contemporary trends in rural agricultural commercialization among wealthy farming households have involved increasing land acreages for these farms. The discussion of such developments can be situated in the context of the new role of the state, international financial circles and development agencies in the village economy. State-rural relations in the late 1980s 
and in the 1990s involve the state and international investors and aid agencies financing rural farm credit and inputs for cash (export) crop production, provision of market incentives, extension services, transportation facilities and payment of relatively high farm produce prices for cash crops. In a number rural communities in Ghana, the Ministry of Agriculture and the Cocoa Services Division of the Cocoa Marketing Board have provided farm technology, inputs and services for cash croppers (Mikell, 1989:219). In the research region, the availability of farm credit from the local Rural Bank has been a major factor encouraging cash cropping activities including the expansion of farm acreages. The bank's active support for cash (tree) crops has far exceeded that for food production. In 1990, among the research sample 450 households in the Ayirebi town, only 82 (18 per cent) received some form of credit assistance from the bank specifically earmarked for domestic food production activities. Since the greatest proportion of cash croppers are males, women food producers are still at a disadvantage in seeking farm credit.

What has been the impact of these recent developments on the local forest environment and land? The emergence and re-emergence of cash (tree) has placed new strains on land acquisition. Although land tenure for cocoa farming in all the research communities was initially lineage and usufruct based, today's farmers are utilizing outright purchase lands and those obtained as leaseholds (rent). Cash crops bring in additional income and other material benefits and producers are able to acquire more lands for extended cash croppıng activities. Customary land tenure relations are being transformed with the restructuring of rural production activities. Tree crops have longer gestation and maturation periods and thus require private or co-operative ownership and good access to credit (Ewusi, 1984). Within the whole study region, there is general resentment of the matrilineage when group land is utilized for tree cropping. It is argued that tree crops tie up land for a lengthy period and consequently limit the opportunities for other family members to have access to 
land for food production. All these factors help to explain why tree croppers would utilize more and more of outright purchase lands. In tree cropping extensive areas are cleared of forest trees and there is a significant impact on local deforestation processes than would normal small-size food farms. In food farming, there is partial clearing of the natural vegetation cover on proposed farm plots. A good number of big trees are left standing to provide shade for the crops and protection to the soil, and to assist reforestation. Since these farms are generlaly small and isolated fields, they are easily recaptured by natural vegetation. The system of mixed and sequential cropping associated with food farming also serves to maintain a green canopy over the ground until the last crop is harvested. By maintaining a constant vegetation cover over the soil, the damage of rain and sun is reduced.

The majority of local residents continue to rely on communal lands for daily sustenance. Table 4 shows the responses of 340 households among the total research sample of 450 households in 1990 from the Ayirebi town who could provide information going back to the 1970s, on the chief source of land acquisition for the main food farm plot. The data basically shows a rapid acceleration of trends and a differential in rates of change and land use among the households. Dei (1990a) discussed the reasons behind the noted changes. The findings of a gradual shift to the reliance on self-acquired lands and the associated trends toward cash (tree) cropping are all part of the on-going processes of the steady loss of communal control over land and the replacement of kin-group access and control by individual access and control. In a related study, the type of farmland for tree cutting activities among the Ayirebi sample households were examined for the periods between September 1982 and August 1983, and also for the summer and fall months of 1989 and 1990. Table 5 shows that in examining the sources of land utilised for farming among sampled households, the high proportion of trees cut are from individually acquired lands. In collecting this information trees counted were the large ones with 
an average height of about 60 metres and which were felled by chain saws, axe and bulldozer. The information provided here have been obtained on the basis of cases reported to the Town Development Committee (TDC) and the Committee for the Defence of the Revolution (CDR), as well as this researcher's attention during the course of various field projects specifically in the Ayirebi town (see Dei, 1990c:12). On self-acquired lands, there is no prerequisite for group consent before cutting big trees. Customary safeguards prohibiting indiscriminate tree cutting activities on communal property regimes cannot be enforced on individually acquired land plots. Landlords exercise their rights to the sale of trees to local timber contractors and artisans.

\section{REASONS AND THE RESPONSIBILITY FOR TREE CUTTING}

The examination of local tree cutting activities shows that on the average a big tree is cut every other day in each of the communities studied. Those responsible for cutting trees include local farmers in the course of their farming activities, women in search for firewood for household energy requirements, artisans engaged in woodcarving and other forms of fibre work, charcoal producers, local timber contractors and multinational logging companies. Fuelwood is the main source of energy for over 80 per cent of African peoples (Webley, 1986; Ki-Zerbo, 1981; Hall, Barnard and Moss, 1982). In a study of fuelwood dependency in sub-saharan Africa, it was shown that fuelwood constitute 94 per cent of the total energy consumption of Burkina Faso, Benin ( 86 per cent), Ethiopia ( 82 per cent), and Ghana ( 74 per cent) [Hall, Barnard and Moss, 1982]. The forest trees are rapidly being cut at the rate of at least $2.7 \mathrm{~m}$ hectares every year to supply fuelwood and timber for exports (Timberlake, 1985; FAO, 1967, 1981). Charcoal and firewood represent over 75 per cent of the total national energy consumption needs of most countries (Webley. 1986; Arnold, 1978). The high demand for fuelwood for household and industrial 
use far exceeds the trees avallable in the forest regions. The local need for fuelwood is gradually having an impact on local deforestation (Brokensha, Riley, Castro, 1983; Pickstock, 1983). Given the non-availability of commercial energy sources for a rapidly increasing rural population one can only expect the situation to worsen. 9

The study of the average household's search for firewood shows that a female with a mean age of 36 years would travel nearly $3.8 \mathrm{~km}$ in about three hours to collect firewood (Dei, 1990c:14). Graınger (1982) also showed that in Tanzania a total of 300 person-days of labour are needed to provide a household with fuelwood for a single year. Since there is no electricity supply in the research region, households have to depend on firewood to cook their meals and heat their water. Among young males and women traders, charcoal production has become a lucrative economic activity over the years. Local charcoal and firewood are sold to urban wage earners in the cities and towns. Adult male contractors purchase trees from landowners and custodians and employ young men to help in the production of charcoal. The charcoal is then put into bags and loaded into Bedford trucks that visit the various communities on the principal market days for carting to the urban centres. A few local residents deal directly with the urban centres in the sale of firewood and charcoal. Other residents, including women, act as brokers between the tree cutters and the firewood and charcoal dealers in the cities and towns who bring in the trucks to cart products away to the city. In the early and mid 1980s, the presence of chain saws acquired by local migrants deported from Nigeria provided a boost to charcoal production and other forest tree cutting activities of local residents. In 1990, a female trader who collected local firewood occasionally for sale on the nearest urban market of Akyem Oda had an annual earnings of about

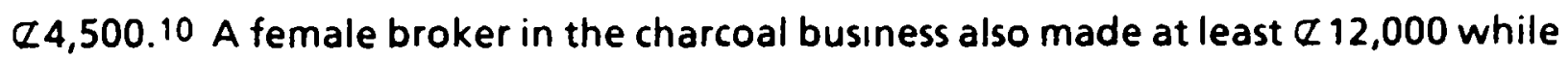
a group of five boys who offered their labour services to charcoal producing entrepreneurs earned a total annual income of close to $₫ 8,000$. An adult male who 
purchased a tree and produced charcoal using both family and hired labour had a net income of over $\not \subset 14,000$ from the sale of charcoal.

The local forest provides a wide variety of plant tree species that can be harvested for household and domestic uses. Local fibre making include basket weaving, straw-work and barkcloth-making, and woodcarving all of which utilize forest raw materials. Local blacksmiths as they reforge and reproduce old farm implements for recycling (e.g., hoes, machetes), are heavily dependent upon the use of wood and burnt charcoal. Among the more popular plants for fibre are Baphia nitida (odwen) Calamus deeratus (mfia), Raphia hookeri (adobe) for rope making and binding material, Bombax buonopozense (akonkodie), Ceiba pentandra (onyina), and Funtumia africana (okae) which produce floss for pillows, and Cocus nucifera (kube) and Elaeis guineensis (abe) which provide fibre for making mats, hats and brooms. For general house construction purposes, forest tree species such as Afzelia bella (papaonua), Albizia zygia (okoro), Blighia unijugatus (akyebiri), Entandrophragma cylindericum (sapele), Hunteria umbellata (kanwene-akoa), Sterculia rhinopeta (wawabima), Sterculia oblonga (ohaa), and Trichilia prieuriana (kakadikuro) are used as planks for buildıng houses. Tree species commonly utilised for woodcarving purposes (stools, tables, chairs, mortars, pestles) include Baphia nitida (odwen), Canthium hispidium (ogyapam), Carapa procera (kwakuobese), Ceiba pentandra (onyina), Cola nitida (bese), funtumia elastica (fruntum), and Xylopia staudtii (duanan) [see also Dei, 1990c:17-22]. The local forest is also exploited for bush animal proteın and other food and medicinal plants (see Dei, 1989). Particularly among forest plants utilised for medicinal and local pharmocological purposes are the bark and stem of Monodora myristica (wedeaba). Carapa procera (kwakuobese) for treating stomach ills and backache and Octoknema borealis (wisuboni) for diarrhea. The leaves of Manihot esculenta (bankye) and Mallotus oppositifolius (nyanyanfrowa) can be used for treating open 
sores, cuts and wounds, and that of Myrianthus arboreaus (nyankoma) for treating boils. The dependence on the forest and its products not only provides additional income for households, but also, indicates to indigenous strategies of utilizing the forest to reproduce rural livelihoods in the midst of a contraction in the national import-dependent economy. As the forest is threatened by deforestation so do rural peoples lose their creative abilities to sustain their livelıhoods. In fact, for the rural poor majority the overwhelming portion of their household incomes comes from the exploitation of forest production.

There are local timber contractors operating in the region negotiating the purchase of trees from landlords and land custodians. These individuals obtain timber concessions from local chiefs and elders and the state for their operations. The contractors only pay nominal fees for each major tree cut. 11 However, it is the activities of the six private and multinational logging firms in the Akyem Oda district that has aggravated the problem of forest trees depletion in the region. 12 Generally, there is no selective harvesting, but the most common wood for logging are Afzelia bella (papaonua), Baphia nitida (odwen), Calamus deeratus, Rattan (mfia), Ceiba pentandra, Kapot (onyina), Chlorophora excelsa (odum), Entandrophragma cylindericum (sapele), Funtumia elastica (fruntum), Mallotus oppositifolius (anyanyanfrowa), Musanga smithii (odwuma), Terminalia superba (ofram), Sterculia tragacantha (sofo), Sterculia rhinopetala (wawabima), and Triplochiton scleroxylon (wawa) [see also Irvine, 1961]. The largest portion of uncultivated forest lands in the country has been nationalized and are considered state property regimes (e.g., forest reserves). On nationalized lands, the state grants concessions for tree cutting to both local and foreign timber firms. Some of these firms have occasionally encroached upon state forest reserves. In the study period of 1989 and 1990, on average ten trucks each with two loads of timber were observed to pass through the Ayirebi town for the saw mills in Akyem Oda. These logging 
firms receive their timber concessions from the state after the payment of royalties and other fees. It was recently revealed that foreign timber operators in some Ghanaian regions sometimes subleased concessions from local timber operators avoiding the tax rate applicable to foreigners and thereby depriving the state of its revenue. 13 In fact the management of some of these firms have links to occupants of local offices (stools), individual entrepeneurs (local contractors) and government agents who are supposed to monitor state forest lands. Some firms can even secure timber rights to local trees without passing through the appropriate state channels. Past governments failed to strictly enforce the rules and regulations on nationalised lands (particularly the forest reserves). The absence of a national development strategy for the tropical forest means there are only a few safeguards for conserving environmentally sensitive areas. At the same time, the state continues to deny local peoples the authority to manage their forests. Apart from illegal logging, there are occasional reports from home communities of the of the wealthy military and political elite securing access to nationalized lands for cultivation purposes.

\section{CONTEMPORARY NATIONAL AND COMMUNITY LEVEL RESPONSES}

The state has begun to realize the vast economic and social potential to be tapped from maintaining and sustaining the forests. In 1983-4, the ruling PNDC government launched a national tree planting exercise and an educational campaign on the consequences of environmental degradation for basic human survival. The campaign involved the planting of millions of tree seedlings nationwide to compensate for the felling of trees for fuel and fibre. The state's efforts have however suffered from a lack of funds to provide adequate and appropriate plant seedlings, and to sustain its publicity campaigns. No detailed feasibility studies have been conducted to address the relevant issues of planting the right trees (e.g., ecologically adaptable species), by the right people (e.g., women and others so 
identified as the backbone of the rural economy), at the right time (i.e., at the onset of the rural farming season), and in the right places (e.g., on the intensively cultivated fields) [see Skutch, 1983]. In fact, nearly 90 per cent of the tree species initially planted have been neglected and died before reaching maturity in most communities. In other cases, logging firms have supported the planting of fast growing foreign tree species (e.g., Canadian Pine and Eucalyptus) that are ready for cutting for the mills in about 12 years. Such trees only serve the short-term economic interests of multınational logging firms with no long-term benefits to the rural peoples. There is evidence at the local level of a few communities that reforestation can make positive advances through the involvement of self-help groups. Rural women are spearheading local self-help efforts fully aware that they are often the first to suffer the consequences of environmental degradation. Communal forest management is being recreated with the adoption of traditional co-operative task force, work groups and associations to encourage tree planting, serve as watchdogs over indiscriminate felling of trees, and offer labour assistance to tree planting on burnt farms. There are on-going discussions in the various villages about the general application of indigenous knowledge and traditions to the problems of the sustainable use of natural resources (Brokensha, Warren and Werner, 1980). Since the late 1980s, local women bodies and church groups have brought pressure to bear on community leaders to take initiatives to redress the problem of deforestation. Among the specific local measures are the establishment of a community forest reserve and woodlot project in the Ayirebi town from an approximately ten hectares of stool land provided by the local chief. Community sanctions and/or penalties have been instituted for indiscriminate felling of trees for superstitious beliefs and also for farming on forest reserves. In the surrounding villages and towns of Adubeasi, Odumase, Kofi Nimo, Abenase and Ofoase, local leaders are exploring ways to regulate commercial felling of trees by chain-saw operators, woodcarvers, charcoal 
makers, and timber contractors. It has been suggested that logging firms be required to plant trees to replace those cut. The eventual success of these communities to deal with the problem would depend to a great extent on how the local peoples themselves retain full ownership and control over their lands.

\section{DISCUSSION}

For long economic development strategies adopted in countries have served to perpetuate a habit of harvesting the forest for immediate needs without any due regard for its long-term sustainability (Winterbottom and Hazelwood, 1987; Caufield, 1986). National forestry development strategies have failed to strike an appropriate balance between competing forces: the need to sustain what is a vital sector of the national economy (production of timber for industrial use and export); an emerging environmental consiousness and agenda (protecting the forest so as to stabilize local ecosystems and preserve biological diversity); and the need to sustain basic livelihoods of rural peoples. Sustainable forestry demands that we integrate conservation and resource development (WCED, 1987). However, conservation should be locally defined, i.e., to take the basic needs of local populations into consideration first. If a resource is to be conserved then it must be to the benefit of those conserving. In other words what is being conserved should be for the eventual disposal of the conservators. Conservation can be promoted if alternative choices and solutions are readily available to people. Local peoples cannot be expected to minimize their dependence of fuelwood if alternative energy sources are not readily available to them. Likewise, if the goal of conservation is to serve the needs of the urban elite and their external accomplices (e.g., multinational logging companies) then local people are not going to embrace any calls for conservation. In some societies forest destruction occurred because rural peoples did not "own" the forest and could neither exclude external intruders. Without having alternative choices or 
some form of local autonomy over available resources, rural peoples have every incentive to cut down the trees before someone else does (Feeny, 1988; Berkes, et al. . 1989:93). The first step to address the situation is to ensure that rural peoples are able to reap the benefits of their own restraint.

In this regard the understanding of local perceptions and responses to the problem of environmental deterioration is significant. For example, as pointed out by Blaikie (1985:12), does deforestation and/or land degradation matter?, and if so to whom? Are there any differences in the perception of local land users and those of multinational logging companies, the state, and even some local political leaders as to the root causes of environmental deterioration or decay? The complexity of human forces at work in the local economy usually leads to a situation where those who do not see themselves as responsible for creating the problem think they should not be held responsible to rectify the solution (see Blaikie, 1989:22). Alternative strategies for development should address issues regardıng the achievement of equality and social justice for all peoples. Rural peoples must be empowered to retain control over the use of resources at their disposal. By promoting local selfdetermination and resource autonomy, ecological integrity can be maintained. The allocation and redistribution of land to the rural poor majority so that they plant and manage their own trees may be promoted within the framework of national development alternatives. The pursuit of this objective does not necessarily entail the removal of kin group control over common resources or substituting instead state property regimes.

It used to be conventional wisdom that resources held in common are vulnerable to overexploitation (Hardin, 1968; Hardin and Baden, 1977). Such assumption has now been challenged by research conducted in the last decade (see Berkes, 1989; Berkes, et al., 1989). The examination of the human forces contributing to local processes of deforestation in this case study leads one to 
question the view that resource degradation is inevitable unless common property is converted into private property or subjected to government regulations (see also Peters, 1987). To the contrary as Berkes, et al. (1989) have argued, communities dependent on common property resources have successfully adopted some institutional mechanisms and arrangements to manage their resources and to achieve sustainable use. There are traditions regarding sustainable forestry that have been practised by many indigenous peoples over the years, particularly as they attributed some forms of quasi-human qualities to the forces of nature.

The myths and traditions held by the study communities include safeguards protecting the indiscriminate fellıng of trees on communal forest lands. As in other rural societies, communal resource users are compelled by social pressures to conform to carefully prescribed and enforced rules of conduct. Local users have to co-operate to achieve common interests and objectives. There are established institutional arrangements regarding who has access and control over such group property, and on what grounds someone is to be excluded within the community. The transformation of traditional institutional mechanisms and arrangements in property rights (e.g., privitization of communal lands) removed community safeguards protecting the forest and its trees. In cases where local institutions have been subverted or manipulated by the state, external forces or even forces from within the community itself for selfish interests (e.g., project motive?), the consequences have not always been beneficial to the local group's long-term interests and survival. As a small wealthy and powerful minority maintain effective control over large portions of available community land and resources, the poor majority are forced to depend and overexploit limited land acreages. With the unequal and differential exercise of effective control over productive resources, the poor cannot be expected to make the kinds of investments in land, labour and capital needed to reverse deteriorating environmental conditions and improve upon 
their social and economic lot (Dei, 1990a; Horowitz, 1988). This is one of the unfortunate long-term consequences of the on-going processes of deforestation in many rural communities. The rural poor would continue to be impoverished as long as they continue to lose control over land as the the major productive resource of society, as well as their abilities to manage and exploit their own forests.

The noted changes in climatic conditions in the past decades (e.g., reduction in annual rainfall, extreme hot and dry conditions and the intensity of the harmattan) are generally affecting the abilitıes of rural farmers to sustain their livelihoods. As climatic conditions worsen, their dependence on the environment and its resources to reproduce their lives in the midst of an on-going severe contraction in the national economies is hindered. Such traditional subsistence and economic practises as hunting and trapping of bush animal protein, collection of wild foods and medicinal plants, utilization of rural arts and crafts as a means of coping with economic hardships no longer become viable alternatives. To rural peoples this is the social reality of the consequences of the continuing degradation of their environments. As part of the search for local solutions, the state must adopt measures and institute tougher penalties to halt the indiscriminate felling of trees by both multinational and local timber companies. The state must regulate the activities of logging firms in the forest resources and other nationalised lands, and should provide material and educational support for national reforestation programs. Viable alternative economic opportunities and other energy sources must be made available to rural peoples. Multinational logging companies must have tree planting as a basic component of their operations in rural areas. The international financial community can also contribute to finding solutions to the problem with such measures as those proposed for Brazil, the debt-for-nature swaps, designed to reduce developing nations huge foreign debts in exchange for projects which protect the environment. The development policies of some international 
financial circles such as the World Bank for developing nations may have to be reexamined as these policies are literally forcing the countries to commit ecocide. 


\section{ACKNOWLEDGEMENTS}

I am thankful to Professor Alejandro Rojas of the Faculty of Environmental Studies, York Unıversity, and some unanimous reviewers for their earlier comments on this paper. I acknowledge financial support for the various phases of my Ghanaian field research from the University of Toronto (Connaught award), Social Sciences and Humanities Research Council of Canada (SSHRCC), and the Dean of Social Science (research associateship) and the Research Board of the University of Windsor. 
NOTES

1. This figure is made up of 2,783 males and 3,022 females and based on the 1984 national population census data obtained from the Government Statistician.

2. Harmattan is a term used since medieval times to refer to the dry, parching land wind that blows along the coast of Upper Guinea during the months of November through March, raising a red dust-cloud that fogs the air.

3. Ghana Meteorological Services, Annual Rainfall reports, Eastern Regional Office, Koforidua, Ghana.

4. Scholars have commented on the sheer mass or variety of the vegetable and animal resources available in this forest region (Irvine, 1961; Wills, 1962). It is important to point out, however, that such prolonged human activities as felling trees for timber, clearing of land and burning of bush for agricultural purposes, and the introduction of new plants have caused great changes in the structure and composition of the climatic-climax vegetation of the region. The result is that much of what is left of the original forest is secondary vegetation consisting of climbers, shrubs, and soft wood plants. The areas of true forest are found in the forest reserves where cultivation and indiscriminate extraction of timber are theoretically forbidden by the state (Boateng, 1959).

5. Sasamansie literally means that which is left by the gods. It is a form of land transaction that recognizes a father's economic investment through personal initiative and effort to improve upon the quality and value of lineage land. A man may be permitted through a mutual agreement with the lineage members 
to give a portion of the lineage land to his children and/or spouse. The transaction is a verbal gift or will made by the father in the presence of lineage elders and other witnesses. The deal transferring such land rights is sealed when the children and/or spouse present a gift in the form of token monetary payment or drinks to the elders and ancestors. The transfer of the land rights may take effect during the father's lifetıme or, as usually the case, immediately after his death.

6. Dei (1990a) has discussed the issue of who rents land and from whom. Many of the renters are poor men and seasonal migrants from northern parts of Ghana and Burkina Faso who have resettled in the community to engage in farming, renting their labour services to wealthy landlords. These landlords are usually family heads and wealthy absentee farmers.

7. In the 1970s, crop diversification among farmers received state support with the launching of the "Operation Feed Yourself" and "Operation Feed Your Industries" programmes by the then ruling National Redemption Council (NRC) government of Colonel Acheampong. Until the late 1980s, however, crop diversification has not been effective in increasıng domestic agricultural output. In most communities only very prosperous farmers have been able to diversify their farm production, and even then in the area of cash (tree) cropping ventures.

8. At the beginning of this century, historical records and oral traditions point to a glut of foodstuffs on Ayirebi markets resulting from a bumper harvest as encouraging some local farmers to engage in cocoa cultivation. Cocoa production was relatively on a minimal scale and only a handful of farmers 
could sustain their interests in the economic activity. Nationwide, cocoa has been the chief crop of most major farming communities in the forest zones of southern Ghana since its introduction in 1879 as a commercial crop. In the 1920s, however, the leading position of cocoa in the farming economies of some of these communities suffered a gradual setback. A series of factors, among them, the lack of adequate farm inputs and credit, shortage of agricultural labour, poor producer prices and the ecological problems of disease (swollen shoot) served to direct attention from the overwhelming emphasis on cocoa to that of staple food crops in some communities (see Senjah 1984; Atsu 1984). In Ayirebi and the surrounding villages where cocoa production was on a limited scale to begin with, these factors only served to reduce the crop's importance in the household economy. The few cocoa farmers decided to devote their time and efforts to food (subsistence) production. It is only in the 1980 s that cocoa production has gradually reemerged in the community.

9. Rural Africa is fast growing in human terms. For the period $1980-85$, the population growth rate was 3.2 per cent per year compared to a world rate of 1.7 per cent and 2.3 per cent for Latin America, the world's next highest. Current projections on the continent's population size put it around 2.6 billion by the year 2030, a steep rise from the 224 million in 1950 and 648 million in the late 1980s. The rural African woman has an average of 6.5 children today (Topouzis, 1991:64). Without a doubt, the rapid population growth has placed immense pressure on land resources, the environment, water supply. employment and health services. Any attempts to check the population growth rate must however be rooted in the socioeconomic context of 
addressing health and educational needs of people and alleviating workloads of rural women.

10. In 1990, the official exchange rate of the local currency, cedi ( $Q$ ) was US $\$ 0.0035$ or US $\$ 1.00$ was worth $\ll 282$.

11. There is no uniform price in the research region for a tree. It is subject to negotiations between individual contractors, companies and tree sellers. But it is general knowledge that the 1990 price offered for trees that ranged from $\mathbb{2}, 000$ to $\mathbb{4 , 0 0 0}$ in the various communities is a far cry from the actual worth and the benefits that tımber contractors obtain from a purchased tree.

12. Prior to the $1980 \mathrm{~s}$, most of the logging firms were either state owned or jointly owned with private individuals and external firms. However, as part of the World Bank's recommendations under the ER/SAPs, the state for the most part has sold its shares to the six private logging firms operating in the region.

13. In 1990, a timber scam in the country involving deals between foreign and local firms was exposed by the National Investigations Committee (NIC) SubCommittee on Timber. The revelation came after charges were made that timber concessions were being taken away from Ghanalans and given to foreigners. It was revealed that between 1986 and 1988 foreign operators subleased concessions from 15 local timber operators, thereby avoiding the higher tax rate applicable to foreigners, and depriving the government of that revenue. The concessionaires also avoided royalties and other related fees by not revealing the number of trees being cut. The PNDC government subsequently revoked the 15 local concessions and granted temporary licenses 
to the foreign firms, so that they can continue working. Foreign firms now have to remit the money which they paid to the local firms directly into a Special Improvement Fund account, and the temporary licences do not give them a right over the concessions. 


\section{REFERENCES CITED}

Ahn, P.M., West African Soils. London: Oxford University Press.

$\checkmark / A \quad$ Arhın, K. 1983. "Peasants in 19th Century Asante." Current Anthropology 24 (4): 471-9.

$\angle A / A$ Atsu, S.Y. 1984. "The Effects of Government Policies on the Increased Production of Food and Food Self-Sufficiency in Ghana." Paper read at the International Conference on Food Self-Sufficiency in West Africa. University of Ghana, Legon, May 1-3, 1984, Accra.

Bennet, G. 1973. "Small-Scale Farming Systems in Ghana". Africa 43: 134-46.

Berkes, F. 1989 (Ed.). Common Property Resources: Ecology and Community-Based Sustainable Development. London: Bellhaven.

Berkes, F., D. Feeny, B.J. McCay and J.M. Acheson. 1989. "The Benefits of the Commons". Nature 340:91-3.

$4 \mathrm{~A} / \mathrm{A}$ Berry, S. 1989. "Access, Control and Use of Resources in African Agriculture: An Introduction". Africa 59 (1): 1-5..

Blaikie, P. 1989. "Environment and Access to Resources in Africa." Africa 59 (1): 18-40.

1985. The Political Economy of Soil Erosion in Developing Countries. London: Heinemann.

Blaikie, P.M. and H.C. Brookfield. 1987. Land Degradation and Society. London: Methuen.

Boateng, E.A. 1959. A Geography of Ghana. London: Cambridge Universtiy Press.

Bolin, B. 1989. "Changing Climates." In Friday, L. and R. Laskey (Eds.) The Fragile Environment. Cambridge:Cambridge Unıversity Press, pp. 127-147.

Brokensha, D.W., D.W. Warren, and O. Werner. 1980. Indigenous Knowledge Systems and Development. Lanham, Md.: University Press of America, Inc.

Brokensha, D.W., B.W. Riley, and A.P. Castro. 1983. Fuelwood Use in Rural Kenya: Impacts of Deforestation. Binghampton, New York: Institute for Deveiopment Anthropology.

Cartwright, J. 1990. "Commitments to Conservation in Africa: Conditions for Success." Paper read at the Annual Conference of the Canadian Association of African Studies, Dalhousie University and St. Mary's University, Halifax, May 912, 1990.

Caufield, C. 1986. In the Rainforest: Report of a Strange, Beautiful Imperiled World. Chicago: University of Chicago Press. 
Dei, G.J.S. 1986. "Adaptation and Environmental Stress in a Ghanaian Forest Community." Unpublished Ph.D Dissertation, Department of Anthropology.

University of Toronto, University Microfilms, Ann Arbor, Michigan.

. 1988. "Crisis and Adaptation in a Ghanaıan Forest Community." Anthropological Quarterly 62 (1):63-72.

1989. "Hunting and Gathering in a Ghanaian Rainforest Community." LC/A
Ecology of Food and Nutrition $22(3): 225-44$.

. 1990a. "The Changing Land Use and Allocation Patterns of a West Atrican Community." Africa Development 15 (1): 25-44.

.1990b. "Indigenous Knowledge and Economic Production: The Food Crop Cultivation, Preservation and Storage Methods of a West African Community." Ecology of Food and Nutrition. $24(1): 1-20$.

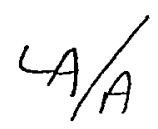

.1990c. "Deforestation in a Ghanaian Community." Anthropologica. 32 (1):3-27.

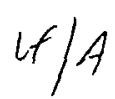

1991. "A Ghanaian Town Revisited: Changes and Continuities in Local Adaptive Strategies." African Affairs, Summer, 1991 (in press).

Eltis, W.S. 1987. "Afrıca's Stricken Sahel." National Geographic 172 (2):140-79.

Ewusi, K. 1984. Dimensions and Characteristics of Rural Poverty in Ghana. Institute of Statistical, Social and Economic Research (ISSER), Technical Publications. University of Ghana, Legon, Accra.

Feeny, D. 1988. "Agricultural Expansion and Forest Depletion in Thailand, 19001975." In J.F. Richards and R.P. Tucker (Eds.) World Deforestation in the Twentieth Century. Durham: Duke University Press, 112-46.

Foley, G., P. Moss, and L. Timberlake, 1984. Stoves and Trees. London: Earthscan. Lf / Food and Agriculture Organization (FAO). 1967. Timber Trends and Prospects in Africa. Rome: FAO and United Nations Economic Commission for Africa. $\angle F A$ Rome: FAOForestry Paper, No. 26. 1981. Forestry and Rural Development. Lf /A

Fortman, L. and J.W. Bruce (Eds.) 1988. Whose Trees? Proprietary Dimensions of Forestry. Westview Press, Boulder, Co.

Friday, L. and R. Laskey (Eds.) 1989. The Fragile Environment. Cambridge University Press, Cambridge.

Grainger, A. 1982. Desertification: How People Make Deserts, How People Can Stop and Why They Don't. Washıngton, D.C.: Earthscan, International Institute for Environment and Development.

Hall, D.O., G.W. Barnard, and P.A. Moss. 1982. Biomass for Energy in the Developing Countries. New York: Pergamon Press. 
Hall, J.B. and M.J. Swaine. 1981. Geobotany: Distribution and Ecology of Vascular Plants in a Tropical Rainforest. London: Junk Publishers.

Hardin, G. 1968. "The Tragedy of the Commons." Science 162: 1243-1248.

Hardin, G. and J. Baden. 1977. (Eds.). Managing the Commons. San Francisco: Freeman.

LA/A Haugerud, A. 1989. "Land Tenure and Agrarian Change in Kenya." Africa 59 (1): 61-90.

$\checkmark$ Hill, P. 1975, "The West African Farming Household." In J. Goody (Ed.) Changing Social Structure in Ghana. London: International African Institute: 119-36.

Hooper, J. 1990. "Structural Adjustment Policies in Ghana, 1983-1990: Sustainable Development?" Paper presented at the Annual Conference of the Canadian Associatıon of African Studies, May 9-12,1990, Dalhousie University and St. Mary's University, Halifax, Nova Scotia.

Horowitz, M.M. 1988. "Anthropology and the New Development Agenda." Development Anthropology Network 6 (1):1-4.

Hutchful, E. 1989. "From Revolution to Monetarism: The Economics and Politics of the Adjustment Programme in Ghana?" In B. Campbell and J. Loxley (eds.) Structural Adjustment in Africa. London: MacMillan.

LF/A Irvine, F.R. 1961. "Woody Plants of West Africa." Economic Botany. 6:23-40. $A B / A$ Ki-Zerbo, J. 1981. :Women and the Energy Crisıs in the Sahel." Unasylva 33 (131):
24-29.

AB/A Kludze, A.K.P. 1983. "Property Law and Rural Development in Ghana". Rural Africana 17:57-67.

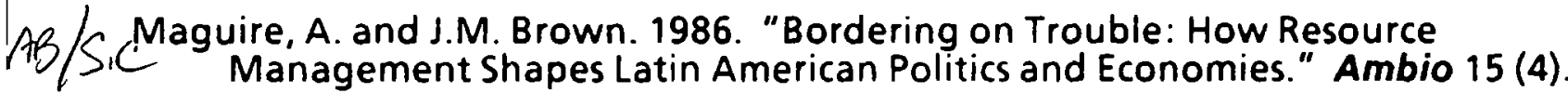

Manoukian, M. 1964. Akan and Ga-Adangme Peoples. London: Oxford University Press.

May, R. 1989. "How Many Species." In L. Frıday and R. Laskey (eds.). The Fragile Environment. Cambridge: Cambridge University Press, pp. 61-81.

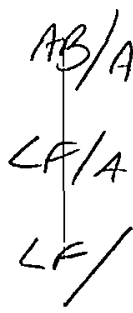

Mikell, G. 1984. "Filiation, Economic Crisis and the Status of Women in Rural Ghana." Canadian Journal of African Studies 18 (1):195-218. . 1989. Cocoa and Chaos in Ghana. New York: Paragon House.

Myers, N. 1989. "The Future of Forests." In Friday, L. and R. Laskey (Eds.).The Fragile Environment. Cambridge: Cambridge University Press, pp.22-40.

$\angle A / A$ Okere, L.C. 1983. The Anthropology of Food in Rural Igboland, Nigeria. University Press of America, Inc., Lanham, Md. 
Okoth-Ogendo, H.W.O. 1989. "Some Issues of Theory in the Study of Tenure $L A / A$
Relations in African Agriculture." Africa $59(1): 6-17$. Peters, P. 1987. "Embedded Systems and Rooted Models: The Grazing Lands of
Botswana and the Commons Debate." In B.J. McCay and J.M. Acheson (eds.). L /A The Question of the Commons: The Culture and Ecology of Communal Resources. Tuscon: University of Arizona Press, pp. 171-94.

PIckstock, M. 1983 . The Fuelwood Crisis in Africa: An FAO Roundtable Discussion. LC/A
Unasylva 35 (141):22-5.

Rattray, R.S. 1923. Ashanti. Oxford. Clarendon Press.

Redclift, M. 1987. Sustainable Development: Exploring the Contradictions. AB/ New York: Methuen

Richards, P. 1983. "Ecological Change and the Politics of African Land Use." African Studies Review. 26 (2):1-72.

. 1985. Indigenous Agricultural Revolution: Ecology and Food Production In West Africa. London: Hutchinson. Rudel, T.K. 1989. "Development and Tropical Deforestation: A Cross-national Study. $L F / T$
Rural Sociology $54(3): 327-38$.

Senyah, J. 1984. "Ghana Cocoa: More than just a Bean." West Africa No. 3482 (May): 1018-9.

Sinclair, L. 1986. "World Economy Can Expand Without Destroying Natural Resources." Ambio 15 (1): 45-46.

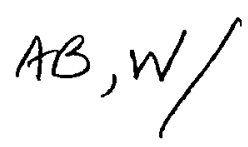

Skutch, M. 1983. Why People Don't Plant Trees: Village Case Studies, Tanzania. Washington, D.C.: Resources for the Future.

Spencer, J. 1966. Shifting Cultivation in Southeastern Asia. Berkeley: University of $\angle A /, O$
California Press.

Timberlake, L. 1985. Africa in Crisis: The Causes, the Cures of Environmental Bankruptcy. Philadephia: New Society Publishers. Toupouzis, D. 1991. "The Problem With People," Africa Report, March/April 1991. L/A
64-66.

Watts, M. 1984. "The Demise of the Moral Economy: Food and Famine in a SudanoSahelian Region in Historical Perspective." In E. Scott (ed.) Life Before the Drought, 1984, edited by. Boston: Allen and Urwin. pp. 124-48. Webley, O. 1986. "Fuelwood." In A. Hansen and D.E. McMillan (eds.). Food in Sub- LF/A
Saharan Africa. Boulder, Co.: Lynne Rienner Publishers. 254-59.

Wills, J.B. 1962 (Ed.). Agriculture and Land Use in Ghana. London: Oxford University Press. 
Winterbottom, R. and P.T. Hazelwood. 1987. "Agroforestry and Sustainable Development: Making the Connection." Ambio 16 (2-3): 100-110.

World Commission on Environment and Development (WCED) 1987. Our Common Future. Oxford University Press, Oxford. 


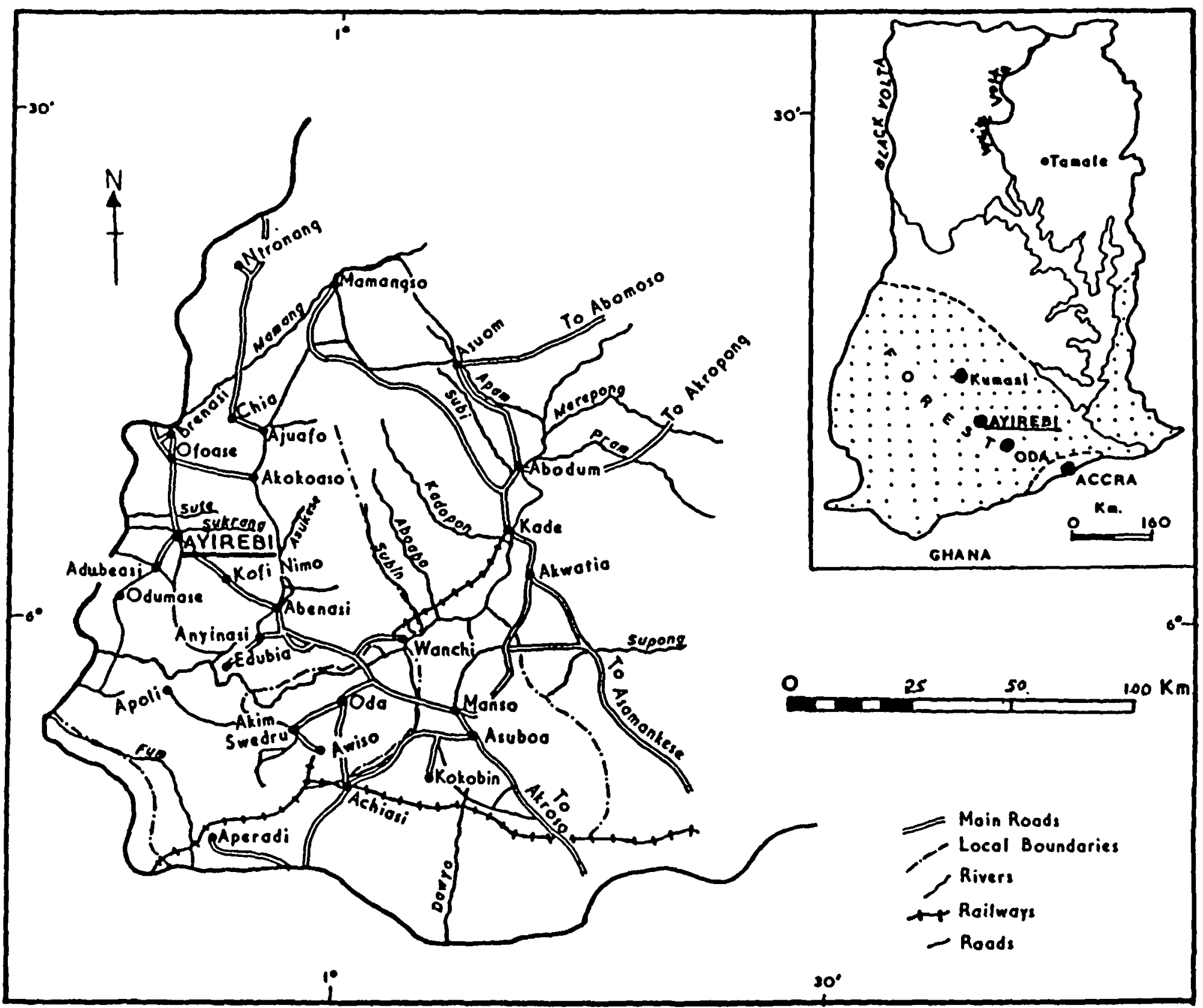

Figure 1 : The Town of Ayirebi and its surrounding villages. 
TABLE 1

DISTRIBUTION OF VEGETATION COVER IN GHANA - 1988*

HECTARES (ha)

$\%$ (millions)

\begin{tabular}{|c|c|c|}
\hline Forest and Game Reserves & 3.8 & 16.0 \\
\hline Unreserved Forest & 0.5 & 2.0 \\
\hline Unreserved Savannah & 7.1 & 30.0 \\
\hline Cultivated Area for Tree and Animal Crops & 2.9 & 12.0 \\
\hline Unimproved Pasture & 3.6 & 15.0 \\
\hline Bush Fallow and other Vegetation Forms & 6.0 & 25.0 \\
\hline TOTAL & 23.9 & 100.0 \\
\hline $\begin{array}{ll}\text { *SOURCE: } & \text { Department of Forestry, Ghana. } \\
\text { Chief Conservator of Forest }\end{array}$ & & \\
\hline
\end{tabular}


TABLE 2

PERIODIC MEAN RATE OF LOSS OF VEGETATION COVER

TO AGRICULTURAL ACTIVITIES* PER ANNUM

(OVER A 10 YEAR PERIOD, 1970-80).**

Vegetation

\begin{tabular}{ll} 
National Forests (Secondary) & 1.18 \\
High Forests (Pure, Reserves) & 0.85 \\
Savannah & 1.24 \\
\hline
\end{tabular}

* Loss to other activities such as bush fires, overgrazıng, cuttıng of fuelwood and timber felling is $3 \%$ per annum.

* Source: Department of Forestry, Ghana. 
TABLE 3

FARMING SYSTEMS AND PROCESSES OF 450 SAMPLED HOUSEHOLDS IN AYIREBI (1989-90)

Farming System/Process

No. \% Households

$\%$

\begin{tabular}{lcc}
\hline \hline Mixed Farming & 410 & 91.1 \\
Crop Rotation & 362 & 80.4 \\
Bush Burning & 410 & 91.1 \\
Construction of Terraces & 79 & 17.6 \\
Bush and Extensive Shifting Cultivation & 194 & 43.1 \\
Intensive Fallow & 438 & 97.3 \\
Permanent Tillage & 150 & 33.3 \\
*See also Dei, 1990a: 28 & &
\end{tabular}


TABLE 4

RESPONSES OF HOUSEHOLD HEADS REGARDING CHIEF SOURCE OF LAND ACQUISISTION FOR MAIN FOOD FARM PLOT CULTIVATED IN FARMING SEASONSI

\begin{tabular}{|c|c|c|c|c|c|c|c|c|c|c|}
\hline \multirow{2}{*}{ FARMING SEASONS } & \multicolumn{2}{|c|}{ LINEAGE 1} & \multicolumn{2}{|c|}{$\begin{array}{l}\text { OUTRIGHT } \\
\text { PURCHASE }\end{array}$} & \multicolumn{2}{|c|}{ RENT } & \multicolumn{2}{|c|}{ STOOL } & \multicolumn{2}{|c|}{ TOTAL } \\
\hline & No. & $\%$ & No & $\%$ & No & $\%$ & No & $\%$ & No & $\%$ \\
\hline $1970-80(n=340)$ & 284 & 83.5 & 39 & 11.5 & 10 & 2.9 & 7 & 2.1 & 340 & 100.0 \\
\hline $1982-83(n=340)$ & 278 & 81.8 & 47 & 13.8 & 9 & 2.6 & 6 & 1.8 & 340 & 100.0 \\
\hline $1989-90(n=340)$ & 279 & 82.0 & 50 & 14.7 & 7 & 2.1 & $\overline{4}$ & 1.2 & 340 & 100.0 \\
\hline
\end{tabular}

1 Lineage land could include land acquired from a spouse's lineage which is held as long as the marriage lasts. 
TABLE 5

TYPE/OWNERSHIP OF LAND REGARDING TREE CUTTING IN AYIREBI $(1982-83,1989-90)^{*}$

\begin{tabular}{|l|c|c|c|c|}
\hline \multirow{2}{*}{ TYPE / OWNERSHIP } & \multicolumn{2}{|c|}{$1982-83$} & \multicolumn{2}{c|}{$1989-90$} \\
\cline { 2 - 5 } & $\begin{array}{c}\text { No. \% Trees } \\
\text { Cut }\end{array}$ & $\begin{array}{c}\% \text { of Total } \\
\text { (151) }\end{array}$ & $\begin{array}{c}\text { No. \% Trees } \\
\text { Cut }\end{array}$ & $\begin{array}{c}\text { \% of Total } \\
\text { (136) }\end{array}$ \\
\hline Lineage & 72 & 47.7 & 67 & 49.2 \\
\hline Stool & 35 & 23.2 & 23 & 16.9 \\
\hline Outright Purchase & 29 & 19.2 & 36 & 26.5 \\
\hline $\begin{array}{l}\text { Rent (Incl. tenancy, lease- } \\
\text { hold and mortgaged lands) }\end{array}$ & 15 & 9.9 & 10 & 7.4 \\
\hline TOTAL & 151 & 100.0 & 136 & 100.0 \\
\hline
\end{tabular}

* See also Dei (1990C): 12. 